\title{
POSISI KYAI BAGI SENTRALISASI MORAL KEHIDUPAN MASYARAKAT
}

\author{
Isnin Agustin Amalia
}

DosenManajemenPendidikan Islam

FITK IAIN Syekhnurjati Cirebon

\begin{abstract}
ABSTRAK
Penyebutan istilah kiyai terhadap seseorang, dalam pembicaraan secara umum ada tiga istilah yang biasa digunakan yaitu kiyai,kiai dan kyai. Melalui tulisan ini, penulis lebih cenderung menggunakan kata kiyai. Di daerah Periangan, kyai disebut ajengan; di daerah Banten disebut abuya (kiyai yang dianggap sangat terhormat atau kiyai besar); Di beberapa daerah di Bekasi dan Karawang, kiyai sering disebut mu'allim yang artinya orang yang berilmu. Penulis cenderung menggunakan makna kyai sebagai suatu gelar kehormatan yang diberikan masyarakat kepada seseorang yang memiliki kedalaman ilmu-ilmu keislaman, di samping karena ketaatan dan kesalehannya dalam menjalankan perintah-perintah Allah dan meninggalkan larangan-laranganNya. Ia dipercaya oleh masyarakat, lantaran ia tidak segan-segan dan tidak bosan-bosan memberikan nasihat ketaqwaan dan kesabaran (wa tawashaw bil-haq wa tawashaw bish-shabr); ia bukan politikus apalagi birokrat; ia bukan pengusaha apalagi manager dalam suatu perusahaan; Sebaliknya, ia adalah seorang pendidik, pengajar dan penganjur ajaran Islam kepada ummat.
\end{abstract}

\section{Kata Kunci: Kyai, Kepemimpinan Kyai, dan Peranan Kyai.}

\section{A. Pendahuluan}

Kiyai merupakan elemen yang paling esensial pada suatu lembaga pendidikan pesantren (Zamakhsyari Dhofier, 1994:55). Jika dipelajari sejarah berdirinya beberapa pesantren di Indonesia, sebagian besar di antaranya termasuk kategori pesantren besar yaitu pesantren yang keberadaanya didirikan atau diprakarsai oleh kiyai; berbeda dengan pesantren yang didirikan atas bantuan masyarakat atau pemerintah yang disebut dengan pesantren kecil. Karena itu, wajar jika beberapa pesantren tertentu pertumbuhan dan perkembangannya sangat bergantung dan dipengaruhi kemampuan dan kemauan pribadi kiyainya.

Kaitannya dengan penyebutan gelar kehormatan kepada seseorang tentang kyai ini, Kafrawi (1978:21) menuliskan, di Aceh kyai disebut teungku bahkan berdasarkan tingkat pemahaman dan kedalaman ilmu- ilmu keislaman, kiyai di Aceh memiliki tingkatan tertentu yaitu sebagai berikut:

1. Teungku Meunasah (kyai yang mengajar anak-anak madrasah tingkat permula-an (madrasah daiyah), di samping menjalankan tugas-tugas kemasyarakatan;

2. Teungku Di Rangkang, kyai yang mengajar santri yang telah selesai dari meunasah;

3. Teungku Di Balai, kyai yang mengajar santri bertempat di Balee yang di kelilingi oleh Rangkang. Para santri di rangkang, setelah menyelesaikan pengajian kitab-kitab tertentu, meningkat menjadi santri di Balee. Jika mereka telah menyelesaikan pengajian kitab-kitab tertentu di Balee, mereka akan memperoleh gelar teungku dengan predikat ulama dan berhak mendirikan dayeuh atau Pesantren, 
4. Teungku Chik atau guru besar, kyai yang mengajarkan santri tentang kitabkitab besar yang termasuk kategori kitab-kitab khusus disebut juga belajar tahasus.

Dipelajari asal katanya, istilah kiyai bukan berasal dari bahasa Arab sebagaimana kata pondok pesantren, santri dan langgar walaupun istilah-istilah ini kental dengan nuansa keagamaan. Istilah-istilah ini diangkat dari kebudayaan atau tradisi daerah tertentu di Indonesia yang kemudian dalam perkembangan berikutnya telah dianggap baku dan mudah dimengerti oleh masyarakat Indonesia pada umumnya. Karena itu, dalam penggunaan istilah ini, di daerah-daerah tertentu di Indonesia, tidak hanya sebagai suatu gelar kehormatan yang diberikan kepada manusia melainkan kepada benda atau binatang.

WJS. Poerwadarminta (1978:505) menuliskan, perkataan kyai dalam masyarakat Indonesia digunakan untuk beberapa keperluan di antaranya:

1. Sebutan kehormatan dari masyarakat terhadap mereka karena ilmu, amal dan akhlaqnya yang merujuk kepada urgen agama Islam, baik terlibat ataupun tidak dengan instansi atau lembaga tertentu seperti pesantren, majlis ta'lim, partai politik atau organisasi,

2. Sebutan kehormatan bagi benda-benda atau binatang tertentu yang dianggap oleh sebagian orang memiliki kekuatan (power) atau keramat (sacre),

3. Sebutan untuk orang yang sudah tua dan dituakan oleh masyarakat dan keluarga, sebagaimana di Kalimantan Selatan dan Lampung.

Pernyataan di atas diperkuat Zamakhsyari Dzofier (1994:55) yang menuliskan bahwa, perkataan kyai dalam bahasa Jawa dipakai untuk tiga bahkan empat jenis gelar yang saling berbeda yaitu:

1. Sebagai gelar kehormatan bagi barangbarang yang dianggap keramat; umpamanya Kyai Garuda Kencana dipakai untuk sebutan Kereta Emas yang ada di Keraton Yogyakarta;

2. Gelar kehormatan untuk orang-orang tua pada umumnya;

3. Gelar yang diberikan oleh masyarakat kepada seorang ahli agama Islam yang memiliki atau menjadi pimpinan pesantren dan mengajar kitab-kitab Islam klasik kepada para santrinya.

Selain gelar kyai, ia juga sering disebut seorang 'alim yang artinya orang yang memiliki kedalaman pengetahuan keislamannya.

Melalui pernyataan di atas, kyai dapat diklasifikasi ke dalam empat golongan yaitu:

1. Kyai dalam pengertian sebagai ulama bebas (bukan ulama-pejabat), yaitu mereka yang memiliki pengaruh karena luas dan dalamnya ilmu pengetahuan keagamaan (fiqh khususnya), karakter pribadi dan karena adanya konsensus dari masyarakat;

2. Kyai dalam pengertian sebagai pejabat agama (ulama-pejabat) yaitu mereka yang kehadiran dan pengaruhnya sangat tergantung dari legitimasinya selain karakter pribadi dan hubungan antara guru dan murid;

3. Kyai sebagai tokoh atau pemimpin pada suatu organisasi masyarakat (Ormas) atau organisasi sosial politik (Orsospol) Islam yaitu mereka yang berpengaruh karena keterlibatannya dalam organisasi;

4. Kyai dalam pengertian sebagai cendekiawan muslim yang terlibat secara langsung ke dalam ilmu-ilmu keislaman yaitu, mereka yang mengaruhnya karena dakwahnya menyentuh pemikiran golongan tertentu di tengah-tengah masyarakat. 


\section{B. Kriteria Kiyai}

Salah satu tujuan santri tradisonal, santri yang tidak belajar di lembaga pendidikan sekolah, memasuki suatu pondok pesantren adalah agar kelak menjadi kyai sebagaimana kyai yang telah membimbing dan mengajarnya tentang aspek-aspek ilmu keagamaan. Selanjutnya ia berharap mampu men-dirikan pondok pesantren sebagai tempat mengamalkan ilmu-ilmu keagamaan kepada para remaja dan pemuda yang mau diajak untuk turut serta melestarikan ajaran Islam (khifdz aldien). Untuk menempuh tujuan ini, mereka bekerja keras dengan senantiasa menuruti segala titah dan/atau mengikuti kegiatan dalam bentuk apapun yang dilakukan kiyai.

Perilaku santri seperti di atas, sebagai upaya untuk menyesuaikan diri terhadap persyaratan menjadi thalab al-'ilm (penuntut ilmu) yang diajukan al-Zarnuji melalui Ta'lim Muta'lim yang dikutip Busyairi Madjidi (1997:107) yaitu antara lain,

1. Cinta ilmu dan hormat kepada guru dan keluarganya, dengan demikian ilmu itu akan bermanfaat;

2. Bersungguh-sungguh dalam belajar dengan memanfaatkan waktu sebaikbaiknya, tetapi tidak memaksakan diri sehingga fisiknya lemah,

3. Ajeg dan ulet dalam menuntut ilmu serta selalu mengulang pelajarannya;

4. Punya cita-citanya seperti burung dengan sayap-sayapnya.

Masyarakat biasanya mengharapkan kepada seorang kyai, yang dapat menyelesaikan persoalan-persoalan keagamaan secara praktis sesuai dengan kedalaman pengetahuan yang dimilikinya. Semakin banyak persoalan-persoalan yang dapat diselesaikannya, maka ia akan semakin dikagumi. Ia juga diharapkan memiliki kemampuan menjadi pemimpin yang dapat melin-dungi masyarakat, dan membukti-kannya melalui pembimbingan, nasihat-nasihat dan arahan terhadap masyarakat yang datang meminta nasihat dan bimbingan. Ia juga rendah hati, menghargai semua orang tanpa melihat tinggi atau rendahnya status sosial, kekayaan dan pendidikan, perihatin dan penuh pengabdian kepada Tuhan serta tidak pernah berhenti memberikan kepemimpinan keagamaan seperti memimpin shalat lima waktu, menjadi khathib jum'ah pada pelaksanaan shalat jum'at dan menerima undangan perkawinan ataupun kematian.

Karena itu untuk menjadi seorang kiyai, menurut Zamakhsyari Dzofier (1994:59), seorang calon harus berusaha keras melalui "perjenjangan" yang bertahap. Ia biasanya merupakan anggota keluarga kyai yang sengaja oleh keluarganya dibentuk menjadi kiyai, karena itu ia dikirimkan ke beberapa pondok pesantren. Setelah ia mampu menyelesaikan pelajarannya di beberapa pesantren, biasanya kyai pembimbingnya yang terakhir melatihnya untuk mendirikan pondok pesantren. Tidak sedikit kyai pembimbing terakhir ini juga turut secara langsung dalam pendirian proyek pesantren yang baru, sebab calon kyai yang dibimbingnya itu dianggap memiliki potensi untuk menjadi seorang kyai yang 'alim dan baik. Campur tangan kiyai pembimbing lebih banyak lagi, di antaranya calon kyai dicarikan jodoh dan diberikan didikan istimewa agar menggunakan waktu terakhirnya di pesantren khusus untuk mengembangkan bakat kepemimpinannya.

Uraian di atas menggambarkan bahwa untuk menjadi seorang kyai, minimal harus memiliki enam kriteria yaitu:

1. Memiliki kemauan atau cita-cita yang kuat dan bekerja keras untuk menjadi kyai,

2. Ada garis keturunan kyai, baik dari orang tuanya, kakeknya ataupun dari mertuanya,

3. Mengikuti perjenjang formal yaitu, memasuki dan mempelajari berbagai kitab klasik Islam di beberapa pesantren, 
4. Dibimbing dan dibina yai yang berpengalaman, dan ia dengan sengaja mengkadernya untuk menjadi calon kyai,

5. Memiliki kemampuan membaca KK, taat beribadah dan tidak pernah melakukan perbuatan yang dilarang Allah,

6. Memiliki bakat menjadi pemimpin dan dipercaya masyarakat.

Orang yang telah memiliki keenam kriteria di atas, dapat dikategorikan sebagai seseorang yang ahli atau memiliki ilmu ('alim) dalam pengertian yang luas yaitu memiliki kedalaman ilmu pengetahuan keagamaan terutama dalam bidang 'aqidah (keimanan), syari'ah (aspek-aspek ajaran Islam) dan siyasah (politik atau ketata kenegaraan) tapi ia tidak sektarian (fanatik madzhab, kelompok atau golongan). Ia bukanlah orang yang aleman (bahasa Jawa, yang segala keinginannya harus dituruti/dipenuhi) atau aliman (bahasa Sunda, yang selalu menolak kehendak masyarakat tanpa mempertimbang-kan kehendaknya apa); sebaliknya ia tegas dalam memberikan nasihat kepada masyarakat terutama kaitannya dengan suatu perkataan dan perbuatan yang dibenarkan atau disalahkan oleh ajaran Islam.

Dengan demikian yang dimaksud kiyai adalah 'alim, yaitu seseorang yang memiliki kedalaman ilmu pengetahuan agama. Kiyai sebagai-mana digambarkan di ataslah yang dikategorikan hadits Nabi sebagai al-'ulamaawaratsat al an-biyaa yakni ulama adalah pewaris para nabi. Betapa mulianya penghargaan dan kedudukan kiyai, sehingga wajar jika terdapat suatu sistem kaderisasi kiyai sebagaimana yang dilakukan kiyai di beberapa pesantren tertentu. Tujuan utamanya adalah semata-mata menghindarkan diri dari perkataan dan perbuatan serta fitnah karena perkataan dan perbuatannya yang dianggap masyarakat tidak sesuai dengan kesucian nama dan misinya sebagai kyai yaitu memberikan nasihat kesabaran dan ketaqwaan kepada masyarakat.

\section{Figur Kiyai}

Sistem kaderisasi kyai, pernah dilakukan KH. Hasyim Asy'ari, pemimpin pondok pesantren Tebuireng, kepada ketiga santrinya yaitu Manaf Abdulkarim, Jazuli dan Zubaer. Sistem kaderisasi yang dilakukan al-mukarram KH. Hasyim Asy'ari tidak hanya sampai ketiga santrinya itu menjadi 'alim; bahkan saat-saat beliau menjelang akhir kepemimpinannya di Pondok Pesantren Tebuireng membentuk suatu kelompok musyawarah, ketiga santrinya itulah yang ditunjuk sebagai guru-guru senior yang diberi tugas. Pertama mengurusi semua santri dan menempatkan santri baru; kedua menemui orang tua santri yang mengunjungi anakanaknya yang mesantren di pondok pesantren Tebuireng. Setelah KH. Hasyim Asy'ari memper-timbangkan mereka dianggap cukup matang untuk memimpin sebuah pesantren, beliau mengatur pernikahan dengan wanita dari desa-desa dimana ketiga kyai muda ini kelak di kemudian hari mampu mengembangkan pesantrennya.

Pada masa-masa permulaan menjadi pemimpin pesantren, mereka bertiga diberi ijazah dan dibekali KH. Hasyim Asy'ari berupa beberapa santri dari pondok pesantren yang dipimpinnya. Beberapa santri kepercayaan KH. Hasyim Asy'ari inilah yang merupakan "modal pertama" bagi ketiga kyai muda tersebut, dalam mengembangkan pondok pesantrennya lebih lanjut yaitu kyai Manaf Abdulkarim mendirikan pondok pesantren Lirboyo (Kediri), kyai Jazuli mendirikan pondok pesantren Ploso (Kediri) dan kyai Zubaer mendirikan pondok pesantren Reksosari (Salatiga, Jawa Tengah).

Pondok pesantren Darussalam (Banyuwangi) yang didirikan pada tahun 1951, sejarah berdirinya, menurut Zamakhsyari Dhofir (1994:60), juga 
mengikuti sistem kaderisasi sebagaimana yang dialami ketiga pondok pesantren di atas. Kyai Mukhtar Syafa'at, pendiri Pondok Pesantren Darussalam, lahir di Kediri dan menghabiskan waktunya sekitar 23 tahun di beberapa pondok pesantren. Pondok Pesantren terakhir yang dimasuki kyai Mukhtar Syafaat adalah Pondok Pesantren Jalen Genteng (Banyuwangi) yaitu antara 1937. Di pondok pesantren ini, ia disamping menjadi santri juga ia membantu kyainya sebagai pengajar beberapa KK dari "KK kecil", "KK menengah" dan "KK besar".

Tahun 1949 adalah hari bersejarah bagi kyai Mukhtar Syafa'at, karena pada tahun itu pemimpin Pondok Pesantren Jalen Genteng menikahkan kyai Mukhtar Syafa'at dengan gadis dari Blok Agung Banyuwangi. Sejak itulah kyai Mukhtar Syafa'at mulai bertempat tinggal di Blok Agung, Banyuwangi. Ketika kyai Mukhtar Syafa'at pindah dari Pondok Pesantren Jalen Genteng ke Blok Agung ini, beberapa santrinya turut pindah ke Blok Agung untuk meneruskan pelajarannya. Blok Agung waktu itu masih sangat jarang penduduknya, tapi dua tahun kemudian, tepatnya pada 15 Januari 1951, kyai Mukhtar (demikian masyarakat setempat dan para santri memanggilnya) bersama para santri dan masyarakat setempat mendirikan sebuah Mushalla kecil berukuran 7x5 M. Mushalla ini, kecuali berfungsi sebagai tempat untuk shalat fardlu berjamaah juga dipergunakan untuk pengajaran KK dan untuk tidur para santri. Dalam waktu satu tahun, mushalla kecil itu berangsur-angsur mengalami berubahan menjadi sebuah Pondok Pesantren Darussalam Banyuwangi.

\section{Peranan Kiyai}

Kiyai, karena ke'alimannya, ketaqwaannya, keikhlasannya dan keistiqamahan-nya sehingga masyarakat mempercayainya sebagai tokoh agama atau tokoh masyarakat yang dianggap mampu menyelesaikan persoalan pribadi maupun golongan. Secara historis, figur kiyai tidak bisa dipisahkan dari kegiatan keagamaan di masjid, madrasah dan pondok pesantren; melalui lembaga-lembaga keagamaan inilah kyai berkiprah dan berperan dalam menjaga dan melestarikan aspek-aspek ajaran Islam dan mengkader para santri sehingga menjadi kyai muda atau masyarakat bermoral.

Kaitan dengan pernyataan di atas, Hiroko Horikosih (1987:115) menuliskan, "terdapatempatgarapan dasar pengabdian kyai di tengah-tengah masyarakat yaitu: 1)Mengabdi di Masjid, 2) Mengabdi di Madrasah, 3) Mengabdi di Pondok Pesantren, dan 4) Mengabdi di Lembaga pendidikan sekolah". Dalam pelaksanaannya, keempat bentuk pengabdian ini bagi kyai tertentu, dilakukannnya secara rutin pada suatu lembaga pendidikan yang ia dirikan yaitu pesantren. Karena itu keempat bentuk kegiatan yang dilakukannya itu, bukan merupakan pengabdian melainkan realisasi dari cita-citanya atau program yang telah direncakannya sejak ia masih berada di pesantren yaitu, jika ia telah selesai mesantrennya akan mendirikan pesantren dengan program pendidikan sebagaimana program pendidikan di tempat ia belajar.

\section{Mengabdi di Masjid}

Ketika seorang santri baru selesai belajar dari pesantrennya dan kembali ke daerahnya, pertama sekali yang dilakukannya adalah melakukan adaptasi dengan kegiatan-kegiatan keagamaan yang diselenggarakan di mushalla/ masjid. Lambat atau cepat, karenakeilmuan yang telah dimilikinya dengan mudah ia diterima dan melibatkan diri atau dilibatkan oleh masyarakat untuk mengamalkan ilmunya. Keterlibatannya dalam membangun daerahnya itu, kisarannya adalah memberikan pembimbingan dan pelatihan ilmu-ilmu keagamaan bagi anak-anak dan remaja. Pendidikan dasar-dasar keagamaanitudiselenggarakan dimadrasah masjid dengan metode khasnya yaitu sorogan, bandongan dan halaqah. 
Beberapa saat kemudian, masyarakat mulai merasakan manfaatnya, maka ia mulai dilibatkan dalam kegiatan keagamaan yang lebih besar yaitu sebagai imam dalam shalat fardlu dan/atau shalat jum'at bahkan dipercaya menjadi khathib dalam shalat jum'at. Pada saat itulah, alumnus santri itu oleh sebagian masyarakat mulai dipanggi sebagai kiyai.

Penyebutan kyai terhadapnya semakin luas, ketika melalui madrasah masjid, ia mengajarkan beberapa kitabkuning (KK) kepada para remaja setempat seperti kitab sufinah al-najah, sulam al-taufiq, tijan al-darari dan nahw al-wadlih. Ia juga menepati atau mendatangi undangan untuk memimpin kegiatan sosial keagamaan dan memberikan ceramah keagamaan. Pendapatpendapatnya tentang sosial-keagamaan sering dan selalu diterima dengan baik oleh masyarakat. Ia juga sering dimintai nasihat oleh masyarakat.

Pernyataan dan kenyataan di atas, merupakan sedikit dari perjalanan dan peranan seorang kiyai di suatu daerah yaitu sebagai imam shalat fardlu, khathib pada shalat jum'at atau menjadi ustadz di madrasah masjid dan menjadi leader dalam kegiatan sosial-keagamaan. Peranan kiyai ini semakin banyak dirasakan dan dianggap menentukan ketika kedudukannya itu berada di wilayah yang lebih luas yaitu di wilayah Kecamatan, di wilayah Kabupaten, di wilayah Propinsi atau di Kepemerintahan pusat. Bahkan di kepemerintahan pusat, peranan kiyai tidak hanya sebagai imam besar masjid, melainkan juga sebagai balancer atau advicer penguasa.

Dengan demikian, peran kyai di masjid tidak hanya sebagai imam al-masjid, tapi juga guru ngaji bagi remaja di madrasah masjid, mubaligh bagi masyarakat, dan advicer bagi penguasa.

\section{Mengabdi di Madrasah}

Pada umumnya, setiap pendidik atau pengajar pada suatu lembaga pendidikan memperoleh honor atau uang kesejahteraan. Bagi kyai tertentu, honor dianggapnya "penghalang" keikhlasannya dalam 'amaliah 'ilmiah. Mengamalkan ilmu, baginya merupakan fardlu 'ain yaitu suatu keharusan bagi setiap pribadi muslim yang memiliki ilmu. Karena itu, mengamalkan ilmu sering kali dinilai sama dengan perbuatan baik(shadaqah) sebagaimana shadaqah bil-mal (harta kekayaan). Sikap kyai yang mencerminkan tanpa pamrih atau lillahi ta'ala inilah yang dimaksud 'ibadah; kyai yang mengamalkan ilmu, disebut 'abid sedangkan perbuatannya dikategorikan sebagai pengabdian (ibadah).

Bagi kyai yang memiliki harta kekayaan yang lebih dari cukup, pengabdiannya di madrasah tidak hanya mengamalkan ilmunya tetapi jugasebagian harta kekayaan yang dimilikinya juga dishadaqahkannya jika ternyata madrasah tempat di mana ia mengabdi itu memerlukan pembiayaan. Tidak hanya sampaia di situ, akal pikiran dan waktunya selalu siap diwaqafkan demi kemajuan madrasah, karena baginya madrasah merupakan salah satutempat untuk mengembangkan syi'ar Islam. Melalui madrasah, ajaran Islam terwarisi kepada generasi berikut sehingga terjaga dari distorsi (hifdz al-dien); melalui madrasah, tumbuh akal cerdas dan kuat (hifdz al'aqal); dan melalui madrasah, keluarga sakinah terbentuk (hifdz al-nasl), karena dari sanalah pendidikan keimanan, keikhlasan, perilaku sosial yang baik dan sikap ketaqwaan tertanam.

Dengan demikian, pengabdian kyai dalam memajukan madrasah begitu kuat dan semangat. Seluruh ilmu yang ia miliki, ia amalkan. Sebagian harta kekayaannya, ia hibahkan/diwaqafkan. Seluruh waktunya, ia luangkan untuk kemajuan madrasah. Karena itu baginya madrasah adalah "jiwa raga" kehidupannya. Kenyataan ini menggambarkan bahwa, madrasah merupakan simbol "api Islam" bagi masa depan ummat Islam. Melalui pengabdian yang dilakukan kyai atau ustadz yang 
ikhlaslah itu "api Islam" akan terus menyala dengan kuat.

\section{Di Tengah-tengah Masyarakat}

Bentuk pengabdian lain yang dilakukan kyai yaitu, memberikan pengajian atau ceramah umum kepada masyarakat. Bentuk pengajian ini, ada yang diselenggarakan oleh kiyai bertempat di rumah pondok pesantrennya, ada juga yang diselenggarakan oleh masyarakat bertempat di masjid atau mushalla. Materi yang disampaikan, kisarannya adalah pahaladosa, janji-ancaman, dan ibadah praktis; metode yang digunakan antara lain: metode qashash (kisah-kisah tauladan), dan amtsal (perumpamaan). Sistem pengajian umum yang berlangsung di suatu tempat ini, dalam teori pendidikan disebut majlis alta'lim (majlis = tempat, ta'lim= belajar). Karena majlis ta'lim merupakan lembaga pendidikan non-formal yang bertujuan mengajarkan dasar-dasar ilmu agama, maka keberadaannya dinilai sangat vital sebagai usaha membina silaturahim.

Bagi masyarakat umum yang menghadiri majlis ta'lim, pengajian yang disampaikan kyai menurut mereka memiliki berbagai arti, antara lain sebagaimana dikemukakan Hiroko Horikosih (1987:117) adalah,

Pertama merupakan amal kebajikan ('amil al-shalih); melalui majlis ta'lim kyai mendorong agar hadirin mencari ilmu agama sebanyak-banyaknya. Ganjaran beramal kebaikan melalui keikut sertaan dalam majlis ta'lim, menurut kiyai, lebih besar daripada shalat sunnah seribu rakaat. Kedua, pengajian berfungsi untuk mengingatkan kembali para hadirin firmanfirman Allah yang telah terlupakan. Ketiga, pengajian merupakan sarana silaturahmi dengan sesama masyarakat muslim atau dengan ulama yang dihormati dan dikaguminya.

Pengajian yang berlangsung di majlis ta' lim berbeda dengan pengajian di pondok pesantren, walaupun disampaikan oleh kyai yang sama. Di majlis ta'lim, pengajiannya bersifat umum sedangkan pengajian di pondok pesantren berupa pelajaran khusus untuk para santri.

Pengabdian kyai dalam membina masyarakat melalui majlis ta'lim, bagi kyai yang memiliki pondok pesantren, memiliki dua peran sekaligus yaitu sebagai tokoh masyarakat juga sebagai pembina santri kalong yang berada di sekeliling pondok pesantren. Pernyataan ini dipertegas oleh Suyata yang pendapatnya diedit Dawam Rahardjo (1985:16) bahwa,

Usaha dan kegiatan yang dilakukan kyai secara garis besar dapat dibedakan atas dua bentuk pelayanan yaitu pelayanan kepada para santri dan palayanan kepada masyarakat. Bentuk pelayanan pertama, melalui pesantrennya ia menyajikan beberapa sarana bagi perkem-bangan pribadi para santri, di samping itu ia berusaha mewujudkan pelayanan kedua yaitu memajukan masyarakat sejalan dengan cita-cita dan kemampuan yang ada.

\section{Pengabdian di Pondok Pesantren}

Kyai sebagai pemimpin pesantren, guru dan panutan pada umumnya juga sebagai pemilik pesantren. Oleh karena itu, kyai sebagai salah satu unsur komponen pendidikan memegang peranan penting dan memiliki otoritas penuh dalam pesantren. Kyai adalah gelar kehormatan yang diberikan oleh masyarakat kepada seorang ahli agama Islam yang memiliki atau menjadi pemimpin disuatu pesantren dan mengajar kitab-kitab Islam klasik kepada para santrinya. Selain gelar kyai, ia juga disebut seorang 'alim.

Sebagai ulama, kyai memiliki peranan dan kewajiban pokoknya adalah mendidik dan mengajarkan pengetahuan agama, menginternalisasikan serta mentransformasikan nilai-nilai agama ke dalam pribadi santri. Ke semua materi yang diajarkan kyai, titik tekanan utamanya adalah merubah sikap dan mental santri ke arah beriman dan bertaqwa kepada Allah swt serta mampu mengamalkan agamanya. Maka secara built-in, kyai atau ulama 
adalah seorang pembimbing hidup keberagamaan umat, sesuai firman Allah dalam al-Quran surat Al-Jumu'ah:2 dan Hadis Rasulullah yang diriwayatkan Imam Bukhari yang artinya, sesungguhnya ulama adalah ahli waris para nabi. Para nabi tidaklah mewariskan emas dan perak, yang mereka wariskan adalah ilmu. Barang siapa mengambil warisannya maka ia mendapatkan keuntungan yang sempurna.

Dengan demikian, kyai sebagai orang 'alim (jama' taksirnya al-ulama) adalah sebagai pewaris nabi yang bertugas sebagai guru (mu'allim), pendidik (muhadzdzib) atau sebagai penghibur hati duka (mubasysyir) dan sebagaipenunjuk jalan (nadzir) sebagaimana halnya fungsi Nabi Muhammad s.a.w. diutus untuk menyempurnakan akhlak, dengan sabdanya yang diriwayatkan Imam Bukhari yang artinya, Aku diutus untuk menjadi guru dan aku diutus untuk menyempurnakan akhlak yang mulia.

Tingkat pengabdian kyai pada pondok pesantren, dapat dilihat dari beberapa faktor antara lain: faktor kepemilikan, kepemimpinan dan amal ilmu. Pertama faktor kepemilikan. Bagi kyai yang ada garis keturunan dengan kyai pendiri, tingkat pengabdiannya dipengaruhi oleh rasa tanggung jawabnya sebagai "pemilik" lembaga yang telah didirikan orang tua atau mertuanya itu. Sehingga seluruh jiwa, raga dan waktunya dicurahkan demi kemajukan pondok pesantrennya. Karena itu, tingkat pengabdian yang dilakukannya sangat optimal. Kedua faktor kepemimpinan. Seorang kyai yang dipercaya oleh kyai atau masyarakat lainnya untuk mengendalikan kepemimpinan pondok pesantren, ia akan berjuang sekuat tenaga untuk memajukan lembaga pendidikan yang dipimpinnya. Karena itu, tingkat pengabdian yang dilakukannya adalah karena rasa tanggungjawabnya sebagai seorang pemimpin. Ketiga faktor 'amaliah 'ilmiah diniyah (mengamalkan ilmu keagamaan). Dedikasi yang tinggi dan tingkat pengabdian yang gigih dilakukan oleh kyai adalah, karena ia merasa terpanggil untuk mengamalkan ilmunya. Ia berpegang kepada salah satu hadits Rasulullah Muhammad saw. yang artinya, 'amal, 'ilmu dan 'alim pada awalnya berada di surga. 'Alim (orang yang memiliki ilmu) akan berada di neraka, sementara 'amal dan 'ilmu tetap berada di surga. 'Alim akan tetap berada di surga bersama amal dan ilmu, jika ia mengamalkan ilmunya.

Dari ketiga faktor itu, yang lebih dominan adalah faktor kesalehan. karena kesalehan, walaupun ia bukan keturunan kyai atau tidak akan pernah menjadi pemimpin pondok pesantren, namun ia tetap mengabdikan jiwa dan raganya demi lestarinya ajaran Islam. Pondok pesantren baginya, sama dengan madrasah yaitu suatu tempat pembinaan keimanan, ketaqwaan, akhlaq dan tempat alih generasi. Jika pengabdian yang dilakukan kiyai melalui madrasah bersifat dorongan moral dari luar, maka pengabdian yang dilakukan kyai di pondok pesantren lebih bersifat memotivasi remaja dari dalam untuk melestarikan dan pewarisan ajaran Islam. Karena itu, kyai yang memiliki pondok pesantren kemudian mengajar remaja di madrasah yang ada di pondok pesantren, adalah pengabdian yang paripurnadi dua tempat sekaligus.

Tumbuh dan berkembangnya kedua pelayanan di atas, sangat dipengaruhi oleh faktor internal dan eksternal pesantren. Pengaruh internal meliputi perkataan dan perilaku para santri akibat dari pengaruh dan pengalamannya sebelum memasuki pondok pesantren, pengaruh dari ustadz karena corak ragamnya metode pengajaran yang digunakan, pengaruh dari informasi yang masuk ke pesantren, kontak dengan masyarakat sekitar pondok pesantren ataupun pengaruh dari program dan suasana pondok pesantren.

Sedangkan pengaruh dari faktor eksternal, pesantren berusaha memajukan masyarakat sekitarnya melalui bekerja sama dengan instansi atau institusi yang memiliki maksud dan arah yang sama. 
Bekerja sama yang dilakukan pondok pesantren, bukan hanya dalam bentuk menghadiri undangan dan/atau memberikan nasihat melainkan lebih dari itu yakni bekerjas sama dalam bentuk menghapus kebodohan, mengangkat harkat dan martabat kebutuhan orang banyak. Bentuk kerja sama ini diwujudkan dalam bentuk mendirikan lembaga pendidikan, baik yang bersifat keagamaan maupun lembaga pendidikan bersifat keterampilan.

\section{E. Kepemimpinan Kiyai}

Seseorang yang dipercaya oleh masyarakat dengan sebutan kyai, bukan semata-mata karena ia mampu membaca alquran atau memahami $\mathrm{KK}$ kemudian mengajarkannya kepada orang lain; juga bukan karena ia menjadi khathib pada shalat jum'at atau pada shalat sunnah 'Idain. Sebutan kyai diberikan kepadanya, karena ia sering membimbing, membina dan memberikan nasihat keagamaan kepada masyarakat sehingga masyarakat merasa terlindungi dari rasa kecemasan, dari rasa takut ataupun terhindar dari kecelakaan yang menimpanya.

Kyai ditengah-tengah masyarakat umum, perilaku dan perkataannya tidak membuat orang lain merasa terhina; ia bergaul dan berbicara dengan siapapun dan selalu bersikap tidak memihak; setiap melakukan suatu perbuatan atau pekerjaan, selalu didasari atas ibadah dan lillahi ta'ala. Perilaku yang demikian itulah, terutama ketidak berpihakannya, sehingga ia sering dipercaya sebagai tokoh masyarakat atau tokoh agama. Dipelajari dari kemampuannya dalam memimpin (menjadi imam) shalat, kemampuannya dalam memimpin berbagai kegiatan 'ritual' keagamaan, kemampuannya dalam melindungi masyarakat dari rasa takut dan cemas ataupun sering dipercaya untuk mewakili masyarakat dalam suatu hajatan pernikahan atau hitanan, maka wajar jika kyai dipercaya sebagai pemimpin masyarakat (social leader). Kenyataan ini diperkuat hasil penelitian Horikosih (1987:1) yang mengemukakan bahwa,
Kyai merupakan pimpinan kharismatik dalam bidang agama. Ia fasih dan mempunyai kemampuan yang cermar dalam membaca pikiran pengikutpengikutnya; sifat atau ciri khas kyai adalah terus terang, berani dan blak-blakan. Oleh karena sifatnya yang kharismatik, maka posisi kyai dalam masyarakat hanyalah bersifat sementara dan cepat berakhir; Pada saat otoritasnya tidak lagi didukung oleh kesinambungan kelembagaan, maka ketridak-berhasilan kyai dalam menanamkan kharisma kepada para pengikutnya akan berakibat menurun kewibawaannya.

Pernyataan di atas menggambarkan bahwa, pengaruh dan kekharismaan kyai tergantung kepada kualitas pribadi, kesalehan dan kemampuannya dalam memimpin masyarakat. Ke semuanya itu tidak bisa diwariskan kepada putranya sekalipun. Kedudukan seorang kyai sebagai pemimpin masyarakat berlangsung tidak melalui pemilihan, karenanya bentuk kepemimpinannya bersifat nonformal dan lokal. Dalam kepemimpinan nonformal, tidak dikenal adanya sistem periodisasi sehingga 'jabatannya' tidak bisa diserahkan kepada orang lain; ia tidak mengangkat pembantu (personalia) secara formal, sehingga cenderung otoriter; bagi kyai yang memiliki suatu lembaga kependidikan, biasanya dalam memanag lembaganya itu tidak berkiblat kepada bentuk kepemimpinan manapun, karena itu dalam melaksanakan pekerjaannya seringkali tidak terencana dengan baik. Namun demikian, pemikiran dan hasil kerjanya selalu dianggap sebagai barang baru sehingga kiyai sering disebut sebagai 'agen pembaharu' yang selalu diterima dan dilaksanakan masyarakat. Meninggalnya seorang kyai, biasanya menjadi pertanda berakhirnya fenomena pimpinan pemersatu dan sekaligus kehi-langan kekuatan bagi kelangsungan hidupnya.

Berbeda dengan bentuk kerpemimpinan yang ada pada dunia pendidikan yang sebagian besar berkiblat 
kepada bentuk kepemimpinan di perusahaan. Kepala sekolah pada suatu lembaga pendidikan sekolah terkadang berfungsi sebagai manajer yang gaya dan seni kepemimpinannya sangat diharsapkan akan mampu memajukan dan mengembangkan atau meningkatkan sekolah yang dipimpinnya. Walaupun kepemimpinannya masih berkiblat pada perusahaan, personalia di lembaga pendidikan memiliki ciri-ciri yang berbeda dibandingkan dengan personalia yang ada pada perusahaan yang jumlah personalianya lebih banyak. Perusahaan yang berstatus milik pribadi, biasanya bentuk kepemimpinannya berada pada lingkungan kekerabatan atau kekeluargaan.

Kepemimpinan dalam tulisan ini adalah, seni dan gaya kepemimpinan kyai dalam memanfaatkan seluruh potensi yang ada di pondok pesantren demi tercapainya tujuan pondok pesantren. Manifestasi dari seninya yaitu cara meng-gerakkan dan mengarahkan unsur-unsur pelaku pondok pesantren dalam berbuat sesuai dengan kehendak pemimpin. Pemimpin di lingkungan pondok pesantren, bukan setiap individu warga pondok pesantren dan juga bukan pemimpin unit-unit kerja dalam struktur organisasi pesantren. Pemimpin pesantren yaitu, kiyai yang menjadi tokoh kunci atau pemimpin spiritual pondok pesantren.

Bentuk kepemimpinan kyai di lingkungan pondok pesantren berbeda dengan bentuk kepemimpinan di lembaga pendidikan sekolah ataupun di perusahaan, tetapi kepemimpinan kiyai bisa seperti kepala sekolah atau manager di perusahaan. Kyai bisa seperti kepala sekolah, karena ia memimpin beberapa ustadz (guru ataupun dosen) dan qayyim (wakil kyai yang mengurusi pondok pesantren) yang mengajar di lingkungan pesantren. Kyai juga bagaikan manager perusahaan, terutama bagi pesantren yang telah berbentuk yayasan di mana kiyai sebagai ketuanya. Yayasan "Pesantren" yang dipimpin kiyai dengan didukung para pengurus yang profesional, dalam perencanaan dan perumusan program kerjanya tidak hanya mengutamakan program-program pendidikan keagamaan tetapi program-program kewira usahaan juga dipertimbangkan seperti mendirikan Koperasi, Toserba dan beberapa program kewirausahaan lainnya. Kebijakan akhir dalam perumusan dan perencanaan program yayasan, biasanya ada pada ketua yayasan yakni kiyai. Kenyataan ini menunjukkan bahwa kiyai di lingkungan pondok pesantren, tidak hanya sebagai imam shalat dan khathib pada shalat Jum'at serta memberikan bimbingan dan pengajaran KK kepada santrinya, melainkan ia juga mampu menjadi pemimpin secara umum bagi para pengurus yayasan dan lembaga pendidikan yang ada di lingkungan pesantren-nya.

Pernyataan di atas menggambarkan, bentuk kepemimpinan di pondok pesantren ke semuanya bergantung kepada kiyai (kiyai centries). Sinyalemen ini tidak terlalu salah bagi masyarakat yang sempat nyantri atau menyaksikan dari dekat model kepemimpinan kiyai di pondok pesantren. Sebagaimana dikemukakan Zubaidi Habibullah Asy'ari (1996:31), "masyarakat pesantren layaknya komunitas feodalkeraton, santri sangat takut bila berhadapan dengan kiyai". Sikap takut juga terjadi ketika kiyai mengajar KK, santri bersikap pasif mendengarkan dengan khusu' dan serius; sementara kiyai bersikap aktif berbicara menjelaskan isi atau matan kitab yang sama-sama dipegang kiyai dan santri; tidak ada komunikasi dialog ataupun tanya jawab pada saat berlangsungnya pengajian. Pada bagian lain Zubaidi Habibullah (1996:44) menuliskan,

Di pesantren ada nuansa kultural, akhlaq, ilmu, karamah dan integritas keimanan; kelas masyarakat yang ada pada pesantren, tercipta atas dasar firman Allah dalam Q.s. al-Hujarat: 13, sesungguhnya orang yang paling mulia di antara kamu di sisi Allah ialah mereka yang paling 
bertaqwa. Ayat ini merupakan landasan santri yang patuh, takut atau hormat pada kiyai hakekatnya tidak ditujukan kepada orangnya, jabatan kekiyaiannya atau apapun gelar yang disandangnya. Tapi ditujukan kepada karamah yang diberikan Allah kepada kiyai. Karamah kiyai dimaksud, antara lain berupa ke'aliman atau kedalaman ilmu-nya dan ketinggian akhlaqnya. Para kiyai dengan karamahnya itu, dimata santri adalah orang yang senantiasa dapat memahami keagungan Allah dan rahasia alam sehingga beliau dianggap memiliki kedudukan yang tidak terjangkau oleh kebanyakan orang biasa. Karena karamahnya, santri dan masyarakat menyerahkan kekuasaan yang sangat luas kepada kiyai.

Melalui ungkapan di atas dapat dikemukakan bahwa, ada beberapa faktor sehingga santri merasa takut dan patuh serta hormat kepada kiyainya, antara lain 1) faktor psikologis yakni santri merasa kecil dan rendah diri di hadapan orang yang dianggapnya 'alim dan memiliki keistimewaan yaitu karamah (kemuliaan); 2) faktor tawaddu' santri kepada orang dewasa atau gurunya, sebagai realisasi dari ajaran Islam yang tertanan dalam jiwanya; dan 3) faktor performance keagamaan kiyai sebagai akibat pancaran jiwa dari karamah Allah. Dengan kalimat lain, hubungan kerja kepemimpinan kiyai terhadap masyarakat pesantren dilandasi tiga kata kunci yaitu: "ikhlas", "berkah" dan "ibadah".

\section{PENUTUP}

Dari uraian di atas dapat dikemukakan, model dan gaya kepemimpinan kiyai dapat dikategorikan sebagai pemimpin yang memiliki ciri kebapakan (paternalistik). posisi kiyai, pada bentuk kepemimpinan ini, bersifat pasif sebagai seorang bapak yang memberikan kesempatan kepada anakanaknya untuk berkreasi, tapi pada saat yang sama kiyai terkadang bertindak otoriter dengan memberikan kata-kata final untuk memutuskan apakah kreasi anak buahnya itu dapat diteruskan atau harus dihentikan (Mastuhu, 1996:80).

Dengan demikian, bentuk kepemimpinan yang dikembangkan kiyai dalam mengendalikan pondok pesantrennya adalah atas dasar anugerah Allah melalui firmanNya terutama pada Qs. 2/alBaqarah:30 sesungguhnya Aku jadikan manusia menjadi pemimpin di muka bumi); Qs. 33/al-Ahzab:72 sesungguhnya kami menawarkan al-amanah (kepemimpinan) kepada manusia, maka mereka pun menerimanya. Karenanya dalam menjalankan tugas kepemimpinannya, Allah memberikan batasan untuk mengeluarkan manusia dari kegagalan menuju terang-benderang dengan ijin Tuhan Maha Kuasa (Qs. 14/Ibrahim:1); mendahulukan pihak lain atas diri mereka walaupun mereka sendiri dalam kebutuhan (Qs. 59/al Hasyer:9), tidak mengikuti hawa nafsu (Qs. 20/Thaha:16 dan Qs. 38/Shaad:26).

\section{DAFTAR PUSTAKA}

Abdul Qadir Djaelani. 1994. Peran Ulama dan Santri dalam Perjuangan Politik Islam Di Indonesia. Surabaya: Bina Ilmu.

Abdurrachman Wachid, 1979. Pesantren sebagai Subkultur dalam Dawam Rahardjo (Ed) Pesantren dan Pembaharuan. Jakarta: , LP3ES.

Abu Hamid, 1993. Sistem Pendidikan Pesantren dan Madrasah di Sulawesi Selatan dalam Taufiq Abdullah (Ed), Agama dan Perubahan Sosial. Jakarta Rajawali.

Achmad Tafsir, 1995. Epistemologi Pendidikan Islam. Bandung: Rosda Karya.

1992. Ilmu Pendidikan dalam Perespektif Islam, Bandung : Rosda Karya.

Dawam Rahardjo, 1982. Gambaran Pemuda Santri dalam Taufiq Abdullah 
(Ed)Pemuda dan Perubahan Sosial. Jakarta: LP3ES.

(Ed), Pesantren dan Pembaharuan, LP3ES, Jakarta, 1986

Horikosih, Hiroko. 1987. Kiyai dan Perubahan Sosial, Jakarta: P3M.

Karel A. Steenbrink. 1978. Pesantren, Madrasah dan Sekolah. Jakarta: LP3ES.

Marwan Saridjo. 1996. Sejarah Pondok Pesantren di Indonesia, Jakarta: Karya Bhakti.

Mastuhu, 1994. Dinamika Sistem Pendidikan Pesantren Suatu Kajian tentang Unsur dan Nilai Sistem Pendidikan Pesantren, Jakarta: INIS.,

Moh. Rusli Karim. 1996. Pendidikan Islam sebagai Upaya Pembebasan Manusia, dalam Muslih Usa (Ed) Sistem Pendidikan Islam di Indonesia. Jakarta: Tiara Wacana.

Nasution, Harun. 1998. Iptek berwawasan Moral, Perspektif Filsafat dan Pemikiran Islam dalam Mastuhu, dkk (Ed), Iptek Berwawasan Moral. Jakarta: IAIN Syarif Hidayatullah Press.

Perlunya Menghidupkan Kembali Pendidikan Moral, dalam Saiful Mujani dan Arief Subhan (Ed) Pendidikan Agama dalam Perpektif Agama Agama, Dirjen Dikti, Depdikbud, Jakarta, 1995

Nurcholis Madjid. 1982. Kurikulum Pondok Pesantren dalam Dawam Rahardjo (Ed) Pesantren dan Pembaharuan. Jakarta: LP3ES

Sudjoko Prasodjo. 1982. Profil Pesantren, Jakarta: LP3ES.

Suyoto, 1985. Pesantren dan Pendidikan dalam Dawam Rahardjo (Ed), Pergulatan Pesantren. Jakarta: P3M.

Umar Hasyim. 1998. Mencari Ulama Pewarisa Nabi Selayang Pandang Sejarah Ulama. Surabaya: Bina Ilmu.
Undang Undang RI Nomor 2 tahun 1989 tentang Sistem Pendidikan Nasional, 1989

Wahjoetomo. 1997. Perguruan Tinggi Pesantren: Pendidikan Alternatif Masa Depan, Jakarta: Gema Insani Press.

Zamachsyari Dzofier. 1984. Tradisi Pesantren Studi tentang Pandangan Hidup Kiyai. Jakarta: LP3ES.

Zubaidi Habibullah Asy'ari, 1996. Moralitas Pendidikan Pesantren, , Yogyakarta: LKPSM. 